\title{
Quality characteristics and sensory evaluation of Fuji apple based on commodity price
}

\author{
Kyung Hyung $\mathrm{Ku}^{*}$, Eun Jeong Choi, Sang-Seop Kim, Moon Cheol Jeong \\ Food Distribution System Research Group, Korea Food Research Institute, Seongnam 13539, Korea
}

\begin{abstract}
상품 가격에 따른 사과의 품질 특성 및 관능 평가
\author{
구경형*·최은정 · 김상섭 · 정문철
}

한국식품연구원 안전유통연구본부 저장유통연구단
\end{abstract}

\begin{abstract}
This study investigated the sensory attributes and quality characteristics of Fuji apples based on market commodity price to provide data for quality index of Fuji apples. Samples were purchased from the Garak market (Seoul Agro-Fisheries \& Food Corporation) and divided into four groups depending on the price such as group A, B, C, D. There were no significant differences in their volume and weight among groups. In the soluble solid content and total free sugar, A and B group (high price) showed higher content than those of $C$ and $D$ (low price) group. And also, the A group and B, C , D group showed $386.29 \mathrm{mg} \%$ and $320.09 \sim 359.28 \mathrm{mg} \%$ in the total organic acid content, respectively. As an sensory evaluation results, A group and B group were evaluated higher score than those of C and D group in the uniformity of red color and glossiness of skin and unique apple sensory attributes using quantitative descriptive analysis. Consumer test showed similar to quantitative descriptive analysis results in the various sensory attributes. In the analysis results between quality characteristics and sensory attributes of Fuji apples, total acceptability was correlated positively with titratable acidity $(\mathrm{r}=0.58)$, soluble solid $(\mathrm{r}=0.89)$, soluble solid content/titratable acidity ratio $(r=0.42)$, total free sugar $(r=0.36)$ and total organic acid $(r=0.38)$. Based on principal component analysis of apple's quality characteristics, apples were primary separated along the first principal component (pH, acidity, soluble solid content, total free sugar, organic acid), which accounted for $66.01 \%$ of total variance. In addition, principal component analysis of sensory evaluation revealed a total variance for the quantitative descriptive of 55 . $65 \%$ and a total variance for the consumer test of $55.84 \%$.
\end{abstract}

Key words : Fuji apple, commodity price, quality characteristics, sensory evaluation

\section{서 론 \\ 사과는 우리나라에서 가장 많이 재배되는 과일로 2015년 사과의 총생산량은 52만 7천 톤이고, 재배 면적 비중이 가장 높은(63\%) 만생종 후지 생산량은 약 32만 7천 톤으로 추정 되고 있다. 2014년 연간 과일 소비량은 1980년대에 $22.3 \mathrm{~kg}$}

*Corresponding author. E-mail : khku@kfri.re.kr Phone : 82-31-780-9052, Fax : 82-31-709-9876

Received 21 September 2016; Revised 7 November 2016; Accepted 8 November 2016.

Copyright (C) The Korean Society of Food Preservation. All rights reserved.
에서 2014년 $66.5 \mathrm{~kg}$ 으로 증가하였고, 일반감귤 및 천혜향, 한라봉 등을 포함한 감귤류가 $14.3 \mathrm{~kg}$ 으로 1 위, 두 번째가 사과로 연간 일인당 $9.4 \mathrm{~kg}$ 을 소비되었다고 보고되었지만 (2), 사과는 우리나라 소비자에게 기호도가 높은 과일로 각광을 받고 있다(1-4).

사과는 2016년부터 도매시장을 제외하고 총 중량에 의거 하여 다양한 포장형태로 유통되고 있으나 일반적으로 크기 가 클수록 높은 가격에 유통되고 있다(5). 국내 소비자의 경우 과일을 구입할 때 가격보다는 품질을 고려하는 것으로 알려져 있는데 특히 사과는 크기가 클수록 시장 가격이 높게 형성되어 있다(5-8). 최근 수입산 과일의 증가와 함께 소비자 측면에서의 농산물 개발에 관심을 가지고 이에 대한 
연구가 시도되고 있다. 소비자와 관련된 사과에 대한 연구 로는 Cho 등(9)의 소비자 기호도 및 인지도 조사, 사과 소비 행태와 이용실태 조사(3), 과실 크기에 대한 소비자 선호 변화 전망(6), 사과의 이상적인 크기와 소비자 기호도 결정 인자 분석(4) 등이 있다. 외국의 경우는 사과 소비 증진을 위하여 유럽 7개국 약 4,300여 명의 소비자를 대상으로 11 개 사과 품종에 대한 소비자 검사 및 훈련된 패널에 의한 관능검사를 수행한 연구(10)와 Seppa 등(11)이 소규모의 소비자 대상으로 검사를 하여 사과를 그룹화한 연구가 보고 되었다.

최근 생활수준이 향상됨에 따라 양적인 측면보다는 질적 인 측면이 강조되어 다른 농산물과 마찬가지로 과일의 소비 성향도 바뀌어 가고 있어 소비자 지향적인 과일의 품질과 유통 개선에 대한 연구가 시도되고 있다. 또 가족 구성원의 감소 및 국내 과일 소비 확대를 위한 작은 크기의 사과 품종 개발하여 보급을 확대하고 있고(10), 소비자가 원하는 사과의 품질에 대한 연구(11)가 일부 진행되고 있다.

본 연구는 소비자 측면에서 후지 사과의 객관적인 품질 개량화 및 등급화를 위한 기초 자료를 얻기 위하여 시장에 서 유통되고 있는 상품 가격에 따른 후지 사과를 수집하여 품질 특성 및 관능특성을 비교 분석하였다.

\section{재료 및 방법}

\section{실험재료}

2014년 11월에 수확되어 유통되고 있는 동일 등급(50개 들이 사과 $/ 15 \mathrm{~kg}$ )의 후지사과 중 가격 차이별로 4 개 그룹을 구입하여 시료로 사용하였다. 이때 A 그룹은 115,000 원/15 $\mathrm{kg}, \mathrm{B}$ 그룹은 84,000 원 $/ 15 \mathrm{~kg}$, C그룹은 59,000 원 $/ 15 \mathrm{~kg}, \mathrm{D}$ 그룹은 37,500 원 $/ \mathrm{kg}$ 으로 가락시장에서 구입을 하였고, 시 료는 박스째 비닐로 밀봉하여 $0^{\circ} \mathrm{C}$ 에 보관하며 사용하였다. 이때 사과의 크기는 김 등(13)의 소비자 기호도 검사 결과 이상적인 크기라고 평가되었던 한 개당 254 375 g 사이의 무게(50개들이)를 지닌 사과를 선발하였다.

\section{이화학적 품질 특성}

사과의 부피와 무게는 volscan profiler(VSP600, Stable Micro System Ltd., Haslemere, England)로 부피와 무게를 측정하였다. $\mathrm{pH}$ 와 산도는 사과의 껍질과 씨방을 제거하여 blender(MR-5550 MFP, Braun, Poland)로 갈아 반죽(paste) 상태로 제조한 후 $\mathrm{pH}$ 는 시료 $4 \mathrm{~g}$ 을 $50 \mathrm{~mL}$ 팔콘 튜브에 넣고, 증류수 $36 \mathrm{~mL}$ 을 혼합하여 1 분간 vortex하고, 10,000 $\mathrm{rpm}$ 에서 20 분간 $4^{\circ} \mathrm{C}$ 에서 원심분리하여 상등액의 $\mathrm{pH}$ 를 측 정하였다. 적정산도의 경우는 $\mathrm{pH}$ 측정에서 사용한 시료 의 상등액 $10 \mathrm{~mL}$ 에 증류수 $20 \mathrm{~mL}$ 를 넣고 교반하면서 0.01 $\mathrm{N} \mathrm{NaOH}$ 로 $\mathrm{pH} 8.20$ 까지 적정하여 소비된 양을 malic acid로
환산하여 \%로 나타내었다(12). 또 가용성고형물 함량은 사 과의 껍질과 씨방을 제거하여 blender로 마쇄한 시료 중 $4 \mathrm{~g}( \pm 3 \mathrm{mg})$ 을 취하여 $50 \mathrm{~mL}$ 팔콘 튜브에 넣고, 증류수 $36 \mathrm{~mL}$ 을 혼합하여 1 분간 vortex 하였다. 이후 $10,000 \mathrm{rpm}$ 에 서 20 분간 $4^{\circ} \mathrm{C}$ 에서 원심분리 하여 상등액을 굴절당도계를 이용하여 ${ }^{\circ} \mathrm{Brix}$ 로 측정한 후 희석 배수를 곱해 나타내었다. 한편 유리당은 사과 원시료를 껍질과 핵을 제거한 다음 마쇄하여 $50 \mathrm{~mL}$ 팔콘 튜브에 시료 $4 \mathrm{~g}$ 과 HPLC water 36 $\mathrm{mL}$ 을 혼합하여 1 분간 vortex하고, 원심분리 $(10,000 \mathrm{rpm}$, $20 \mathrm{~min}$ )하였다. 이중 상등액을 취하여 $0.2 \mu \mathrm{L}$ membrane filter로 여과 후, 적정배율(10배)로 희석(DW, HPLC grade) 한 후 HPLC(Agilent 1260, Waldbronn, Germany)에 $10 \mathrm{uL}$ 를 주입하여 분석하였다. 이때 유리당의 분석조건은 Column: YMC-Pack Polyamine $\Pi(250 \times 4.6 \mathrm{~mm})$, 이동상은 Acetonitrile:water=75:25 (HPLC Grade J.T.Baker), Flow rate: $1 \mathrm{~mL} / \mathrm{min}, \mathrm{RI}$ detector(G1362A 1260RID)를 이용하였고, 표준 물질들로 fructose, sorbitol, glucose, sucrose(Sigma chemical Co., St. Louis, MO, USA)를 사용하여 $0.2 ~ 2.0 \%$ 의 농도로 조제하여 사용하였다. 유기산은 유리당 시료와 동일하게 처 리된 시료를 HPLC (Jasco, Tokyo, Japan)에 $20 \mathrm{uL}$ 를 주입하 여 분석하였다. 이때 분석 조건은 Prevail Organic Acid 5 $\mu\left(150 \times 4.6 \mathrm{~mm}\right.$, Grace) column, 이동상: $25 \mathrm{mM} \mathrm{K}_{2} \mathrm{HPO}_{4}(\mathrm{pH}$ 2.8), UV detector, $210 \mathrm{~nm}$, flow rate: $0.8 \mathrm{~mL} / \mathrm{min}$ 이었다. 또 유기산 분석에 사용한 표준물질들은 malic acid, shikimic acid, citric acid(Sigma chemical Co.)를 사용하여 0.01 100 $\mathrm{mg} \%$ 의 농도로 조제하여 사용하였다(12).

\section{관능검사 시료 준비}

외관 평가용 사과 시료는 전체 사과를 제시하여 색의 균일함, 사과 껍질의 윤기를 평가하게 하였다. 과육의 경우 는 자동과일박피기(HFP-130 SP, Hwajinprecision Co., Ltd., Ulsan, Korea)를 이용하여 껍질을 제거한 후, 사과분할기 (HFC-130SP, Hwajinprecision Co., Ltd.)를 이용하여 균일하 게 8 등분으로 분할하고, 소비자 검사시 갈변을 막기 위하여 Corollaro 등(13)의 방법에 따라 ascorbic acid $0.2 \%$, citric acid $0.2 \%$, calcium chloride $0.5 \%$ 에 10 초 동안 담근 뒤 물기 를 제거한 후 검사전까지 밀폐 용기에 담아 보관하였다. 관능검사 평가시 사과 시료는 과육 3 조각을 흰 접시(지름 $14 \mathrm{~cm}$ )에 담아 세자리 coding을 하여 패널원에게 평가하도 록 하였다.

\section{관능검사}

사과의 정량적 묘사 분석을 위한 패널원은 원내 게시판 을 이용하여 약 30 명을 모집한 후 맛 차이에 예민한 패널 요원을 선정하기 위하여 4가지 기본맛(단맛, 짠맛, 신맛, 쓴맛)에 대한 기본 맛 인지 검사 및 순위 검사를 실시하였다. 검사 결과 정답률이 $75 \%$ 이상인 패널을 1 차로 선정한 후 
평소 사과에 대한 구매력 및 지속적으로 본 실험에 참여와 표현 능력 등을 고려하여 12 명 15 명을 2 차로 선발하여 관 능검사를 실시하였다(23). 사과의 정량적 묘사 분석은 훈련 과 본 실험으로 나누어서 진행을 하였고, 패널의 훈련 과정 은 Jung 등(13)과 Collollado 등(14)의 결과에서 선발된 용어 와 표준 지표를 이용하여 약 3주간 훈련한 후 사과의 정량적 묘사 분석의 특성을 9점법으로 평가하였다. 이때 선발된 용어는 외관(2개), 과육의 노란색, 사과 향미, 이취, 단맛, 신맛, 다즙성, 아삭함, 질김성, 가루끼(푸석함)이었고, 시료 는 4 개 그룹의 시료는 동시에 제공하였으며 8회 실시하였 다. 이때 묘사분석에서 평가한 시료는 후지 사과 그룹당 96 개의 시료였고, 총 384 개의 시료를 평가하였다. 한편 소 비자 기호도 검사는 사과를 좋아하고 본 검사에 흥미와 시간적 여유와 의사가 있는 한국식품연구원에 근무하고 있는 20 40대 소비자 100 명이 참여를 하였다. 묘사 분석과 소비자 검사는 컴퓨터가 설치된 개별 부스에서 진행하였 고, 앞에 있는 사과 외관의 붉은색 균일한 정도와 윤기를 평가한 후 사과 과육 순으로 평가하였다. 사과 시료는 4개의 시료가 랜덤화된 순서로 한꺼번에 제시하였고, 과육의 노 란색 정도, 사과 향미, 이취, 단맛, 신맛, 다즙성, 아삭거림, 씹는 동안의 질김성, 가루끼(씹을 때 푸석함)는 9점법을 이용하여 점수가 높아질수록 특성 강도가 강해지는 것으로 평가하였다. 또 전반적인 기호도는 1 점은 기호도가 낮은 것을 나타내고, 점수가 9점으로 갈수록 기호도가 높은 것으
로 평가하게 하였다.

\section{통계분석}

시장에서 유통되고 있는 상품 가격에 따른 후지 사과의 이화학적 특성과 관능검사 결과의 시료 간 차이를 알아보기 위하여 SPSS 18.0을 이용하여 분산분석을 수행하였으며, SNK(Student Newman Keul's) 다중 비교를 하여 시료 간 평균값을 비교하였다. 또 이들 품질 요인간의 상관분석 (correlation analysis)과 주성분 분석(principle component analysis, PCA)은 Xlstat(15)을 이용하였다.

\section{결과 및 고찰}

\section{이화학적 품질특성}

시장 가격별로 구입한 50 개 들이 사과의 이화학적 품질 특성을 조사하여 비교 분석을 한 결과(Table 1), 무게와 부피 의 경우 50 개 들이 시료를 구입한 것이라서 통계적인 유의 차이는 없지만, $\mathrm{A}$ 그룹 $(273.33 \pm 28.66 \mathrm{~g}, 321.85 \pm 33.31 \mathrm{~mL})$ 으로 가장 컸고, B 그룹 $(262.00 \pm 20.97 \mathrm{~g}, 313.39 \pm 26.46 \mathrm{~mL})$, $\mathrm{D}$ 그룹 $(257.67 \pm 27.48 \mathrm{~g}, 312.25 \pm 34.81 \mathrm{~mL}), \mathrm{C}$ 그룹 $(254.33 \pm$ $15.29 \mathrm{~g}, 301.12 \pm 20.85 \mathrm{~mL})$ 의 순서였다. 이는 농산물 품질 규격(16)에서 6단계로 크기 구분한 후지 사과 1개당 250 $300 \mathrm{~g}$ 의 무게에 해당하는 L에 해당하였고, Corollaro 등(14)

Table 1. Quality characteristics of Fuji apples according to commodity price

(unit: \%, mg\% wet base)

\begin{tabular}{|c|c|c|c|c|}
\hline \multirow[b]{2}{*}{ Quality characteristics } & \multicolumn{4}{|c|}{ Apple samples } \\
\hline & A & B & $\mathrm{C}$ & $\mathrm{D}$ \\
\hline Weight (g) & $273.33 \pm 28.66$ & $262.00 \pm 20.97$ & $254.33 \pm 15.29$ & $257.67 \pm 27.48$ \\
\hline Volume (mL) & $321.85 \pm 33.31$ & $313.39 \pm 26.4$ & $301.12 \pm 20.85$ & $312.25 \pm 34.81$ \\
\hline $\mathrm{pH}$ & $3.99 \pm 0.10^{\mathrm{bl})}$ & $4.12 \pm 0.06^{\mathrm{ab}}$ & $4.12 \pm 0.05^{\mathrm{ab}}$ & $4.22 \pm 0.07^{\mathrm{a}}$ \\
\hline Titratable acidity (\%) & $0.32 \pm 0.03^{\mathrm{a}}$ & $0.29 \pm 0.03^{\mathrm{a}}$ & $0.30 \pm 0.26^{\mathrm{a}}$ & $0.22 \pm 0.04^{b}$ \\
\hline Soluble solid (\%) & $13.92 \pm 0.71^{\mathrm{a}}$ & $13.73 \pm 0.96^{\mathrm{a}}$ & $11.19 \pm 0.79^{b}$ & $9.16 \pm 0.34^{c}$ \\
\hline SSC/TA ratio & $44.62 \pm 1.98^{\mathrm{a}}$ & $48.20 \pm 6.61^{\mathrm{a}}$ & $37.61 \pm 3.31^{\mathrm{b}}$ & $42.65 \pm 6.38^{\mathrm{a}}$ \\
\hline Fructose $(\%)$ & $6.34 \pm 0.43^{\mathrm{a}}$ & $6.03 \pm 0.44^{\mathrm{a}}$ & $5.59 \pm 0.70^{b}$ & $4.42 \pm 0.27^{\mathrm{c}}$ \\
\hline Sorbitol (\%) & $0.87 \pm 0.15^{\mathrm{a}}$ & $0.74 \pm 0.24^{\mathrm{a}}$ & $0.56 \pm 0.21^{b}$ & $0.37 \pm 0.07^{\mathrm{c}}$ \\
\hline Glucose (\%) & $2.59 \pm 0.35^{\mathrm{a}}$ & $2.47 \pm 0.42^{\mathrm{a}}$ & $2.32 \pm 0.49^{\mathrm{a}}$ & $1.51 \pm 0.44^{b}$ \\
\hline Sucrose $(\%)$ & $2.15 \pm 0.64^{\mathrm{a}}$ & $1.30 \pm 0.34^{\mathrm{b}}$ & $1.14 \pm 0.37^{b}$ & $1.17 \pm 0.57^{b}$ \\
\hline Total free sugar $(\%)$ & $11.96 \pm 0.89^{\mathrm{a}}$ & $10.53 \pm 1.32^{b}$ & $9.61 \pm 1.38^{c}$ & $7.47 \pm 0.60^{d}$ \\
\hline Fructose/Glucose & 2.44 & 2.44 & 2.40 & 2.78 \\
\hline Malic acid (mg\%) & $372.48 \pm 40.36^{\mathrm{a}}$ & $329.89 \pm 37.81^{b}$ & $346.48 \pm 50.59^{b}$ & $307.86 \pm 32.59^{b}$ \\
\hline Shikimic acid (mg\%) & $0.99 \pm 0.11^{\mathrm{a}}$ & $0.91 \pm 0.05^{\mathrm{ab}}$ & $0.95 \pm 0.12^{\mathrm{ab}}$ & $0.86 \pm 0.12^{\mathrm{b}}$ \\
\hline Citric acid (mg\%) & $12.83 \pm 3.30$ & $13.43 \pm 2.32$ & $11.80 \pm 2.17$ & $11.38 \pm 1.58$ \\
\hline Total organic acid (mg\%) & $386.29 \pm 40.28^{\mathrm{a}}$ & $344.23 \pm 38.56^{b}$ & $359.23 \pm 51.39^{\mathrm{b}}$ & $320.09 \pm 32.24^{b}$ \\
\hline
\end{tabular}

${ }^{1)}$ Means \pm SD ( $\mathrm{n}=36$ ) within each column followed by the same letter are not significantly different $(\mathrm{p}<0.05)$. 
의 이탈리아 시장에서 소비되고 있는 사과 21 개 품종의 특성과 관능 프로파일 연구에서 캐나다에서 재배 수확 후 이탈리아에서 판매되고 있는 후지 사과의 무게가 247 268 $\mathrm{g}$ 인 결과와 비교해서 본 연구에서 사용한 후지 사과의 크기의 경우 244 273 g의 범위로 거의 비슷한 크기였다. $\mathrm{pH}$ 는 $\mathrm{A}$ 그룹이 $3.99 \pm 0.10$ 으로 가장 낮았고, $\mathrm{D}$ 그룹이 $4.22 \pm 0.07$ 로 가장 높았으며, $\mathrm{B}$ 와 $\mathrm{C}$ 그룹은 4.12 로 동일한 $\mathrm{pH}$ 를 보였다. 적정산도는 $\mathrm{A}, \mathrm{B}, \mathrm{C}$ 그릅간 유의적인 차이는 없었으나 가장 높은 그룹은 $\mathrm{A}$ 그룹으로 $0.32 \pm 0.03 \%, \mathrm{C}$ 그룹 이 $0.30 \pm 0.26 \%, \mathrm{~B}$ 그룹이 $0.29 \pm 0.03 \%$ 이었고, $\mathrm{D}$ 그룹이 유 의적인 차이가 있으면서도 가장 낮은 $0.22 \pm 0.04 \%$ 였다. 가 용성고형물 함량의 경우 $\mathrm{A}$ 그룹과 $\mathrm{B}$ 그룹은 각각 $13.92 \pm 0.71 \%, 13.73 \pm 0.96 \%$ 이었고, $\mathrm{C}$ 그룹과 $\mathrm{D}$ 그룹은 $11.19 \pm 0.79 \%, 9.16 \pm 0.34 \%$ 였다. 국립농산물 품질관리원의 농산물 표준 규격(10)에 따른 후지사과의 등급 분류에 의해 특 등급은 14 이상, 상 등급은 12 이상인데, 본 실험에 사용한 후지 사과의 경우 $\mathrm{A}$ 와 $\mathrm{B}$ 그릅은 상등급 이상, $\mathrm{C}$ 와 $\mathrm{D}$ 는 보통에 해당하였다. 한편 사과의 유리당은 주로 fructose, glucose, sucrose와 당알코올인 sorbitol로 구성되어 있고, 사과의 수용성 탄수화물 대부분을 차지하고 있다고 보고 (17-19)되어 있다. 본 연구에서 사용한 사과의 fructose는 $\mathrm{A}$ 와 $\mathrm{B}$ 그룹은 각각 $6.34 \pm 0.43 \%, 6.03 \pm 0.44 \%$ 로 유의한 차이 가 없었으나, C 그룹은 $5.59 \pm 0.70 \%, \mathrm{D}$ 그룹은 $4.42 \pm 0.27$ 로 차이가 있었다. 청량감을 주는 sorbitol 함량의 경우 $\mathrm{A}$ 그룹 $(0.87 \pm 0.15 \%)$ 과 B 그룹 $(0.74 \pm 0.24 \%)$ 은 유의한 차이가 없었 으나, $\mathrm{C}$ 와 D 그룹은 각각 $0.56 \pm 0.21 \%, 0.37 \pm 0.07 \%$ 로 유의 한 차이가 있었다. Glucose 함량은 D 그룹 $(1.51 \pm 0.44 \%)$ 을 제외하고 A, B, C 그룹에 유의한 차이가 없는 $2.32 \pm 0.49$ $2.59 \pm 0.35 \%$ 였다. 반면에 sucrose 함량의 경우 $\mathrm{A}$ 그룹 $(2.15 \pm 0.64 \%)$ 을 제외한 B, C, D 그룹은 차이가 없었으나 총유리당에 대한 비율로 보면 $\mathrm{A}$ 그룹은 $17.98 \%, \mathrm{~B}$ 와 $\mathrm{C}$ 그룹은 각각 $12.32 \%$ 와 $11.86 \%, \mathrm{D}$ 그룹은 $15.66 \%$ 였다. 총 유리당의 함량 순서는 $\mathrm{A}>\mathrm{B}>\mathrm{C}>\mathrm{D}$ 의 순으로 가용성 고형분 함량이 높은 시료가 높은 유리당 함량을 보였고, 특히 fructose함량에 크게 영향이 있었다. 이 결과는 Kim 등(20) 의 1997년 가을에 5개 지역(강원 원주, 경북 대구, 전북 정읍, 충남 예산, 경기 수원)에서 수확한 후지 사과의 유리 당 분석 결과 지역에 따라 총 유리당이 10.70 13.08\%, sucrose $1.70 \sim 2.86 \%$, glucose $2.40 \sim 3.16 \%$, fructose 5.59 $6.96 \%$, sorbitol $0.40 \sim 0.96 \%$ 의 범위에 속하였다. 순수 사과 주스의 검정 지표로 활용할 수 있는 fructose와 glucose 비율 의 경우 Brause와 Rateman(21)은 최소 비율로 1.6 을 제시하 였고, Mattick과 Moyer(22)의 1.67를 최소 비율로 제시하였 다. 또 Elkins 등(17)은 최소 1.71 에서 최대 2.67의 분포로 되어 있다는 보고와 Wrolstad와 Shallenberger(22)는 1.53 5.26의 범위라고 제시한 결과를 미루어 보아 본 연구 에서 사용한 가격별 후지 사과의 경우 2.40 2.78로 세계
다른 지역에서 재배된 후지 사과의 당비율과 큰 차이가 없었다. 사과의 신맛에 관여하는 유기산중 비휘발성 유기 산의 $90 \%$ 이상이 L-malic acid이며 citric acid, succinic acid, quinic acid 등이 있다고 보고되었는데(19) 본 연구에서는 과피를 제거한 과육만을 취하여 분석한 결과로 malic acid, shikimic acid, citric acid가 검출되었다. 총 유기산의 경우 $\mathrm{A}$ 그룹의 시료가 가장 높은 함량인 $386.29 \pm 40.28 \mathrm{mg} \%$, $\mathrm{B}, \mathrm{C}, \mathrm{D}$ 그룹은 $320.09 \pm 32.24 \sim 359.23 \pm 51.39 \mathrm{mg} \%$ 의 범위를 보였고 malic acid 함량이 시료에 상관없이 $95 \%$ 이상을 차지하였다. 이는 Do 등(23)의 5 개 지역에서 수확한 후지 사과의 유기산 측정값인 $366.01 ~ 453.45 \mathrm{mg} \%$ 의 범위에 A 그룹은 속해 있으나, 나머지 시료는 약간 낮은 값을 보였는 데, 이는 분석 조건과 시료 차이에 의한 값으로 여겨진다.

\section{관능적 품질 특성}

시장 가격별로 구입한 50개 들이 후지사과를 Collollado 등(14)의 결과에서 선발된 용어와 표준 지표를 이용하여 약 3 주간 훈련된 패널들에 의해 선발된 후지 사과의 정량적 묘사 분석의 특성을 분석하였다(Table 2). 그 결과 후지 사과 외관의 붉은색의 균일성의 경우 $\mathrm{A}$ 와 $\mathrm{B}$ 그룹은 $6.92 \pm 1.31$ 과 $6.17 \pm 1.47$ 로 높게 평가하였고, $\mathrm{C}$ 와 $\mathrm{D}$ 그룹은 각각 3.58 \pm 0.99 와 $2.50 \pm 1.97$ 로 두 개 그룹으로 나뉘어졌다. 사과 껍질 의 윤기는 $\mathrm{A}$ 그룹이 $6.67 \pm 1.73$ 으로 가장 높게 평가하였고, $\mathrm{B}>\mathrm{C}>\mathrm{D}$ 그룹의 순으로 평가하였다. 사과 껍질을 제거한 과육의 노란색 정도는 $\mathrm{A}(6.45 \pm 1.16)$ 와 B 그룹(7.67 \pm 1.37$)$ 은 유의적인 차이가 없다고 평가한 반면 C 그룹은 $4.67 \pm 1.66$, $\mathrm{D}$ 그룹은 $2.83 \pm 1.95$ 의 점수로 차이가 있게 평가하였다. 사 과향과 단맛, 다즙성, 아삭함의 관능특성에서 $\mathrm{A}$ 그룹과 $\mathrm{B}$ 그룹이 유의적인 차이가 없으면서 $\mathrm{C}$ 와 $\mathrm{D}$ 그룹보다는

Table 2. Sensory attributes of Fuji apple according to value by quantitative development analysis

\begin{tabular}{lcccc}
\hline \multirow{2}{*}{ Sensory attributes } & \multicolumn{4}{c}{ Apple samples } \\
\cline { 2 - 5 } & $\mathrm{A}$ & $\mathrm{B}$ & $\mathrm{C}$ & $\mathrm{D}$ \\
\hline Uniformity of red color & $6.92 \pm 1.31^{\mathrm{a} 1}$ & $6.17 \pm 1.47^{\mathrm{a}}$ & $3.58 \pm 0.99^{\mathrm{b}}$ & $2.50 \pm 1.97^{\mathrm{b}}$ \\
Glossiness of skin & $6.67 \pm 1.73^{\mathrm{a}}$ & $5.17 \pm 2.21^{\mathrm{ab}}$ & $4.00 \pm 2.17^{\mathrm{bc}}$ & $2.50 \pm 1.62^{\mathrm{c}}$ \\
Yellowness of flesh & $6.45 \pm 1.16^{\mathrm{a}}$ & $7.67 \pm 1.37^{\mathrm{a}}$ & $4.67 \pm 1.66^{\mathrm{b}}$ & $2.83 \pm 1.95^{\mathrm{c}}$ \\
Apple flavor & $7.18 \pm 0.83^{\mathrm{a}}$ & $7.99 \pm 0.85^{\mathrm{a}}$ & $3.92 \pm 2.07^{\mathrm{b}}$ & $2.50 \pm 1.83^{\mathrm{c}}$ \\
Off flavor & $2.08 \pm 1.16$ & $2.33 \pm 1.15$ & $2.50 \pm 1.17$ & $3.67 \pm 2.64$ \\
Sweetness & $7.45 \pm 0.65^{\mathrm{a}}$ & $7.36 \pm 1.15^{\mathrm{a}}$ & $3.75 \pm 1.82^{\mathrm{b}}$ & $2.50 \pm 1.31^{\mathrm{c}}$ \\
Sourness & $6.18 \pm 1.59^{\mathrm{a}}$ & $4.98 \pm 1.81^{\mathrm{ab}}$ & $5.00 \pm 2.49^{\mathrm{ab}}$ & $3.42 \pm 2.31^{\mathrm{b}}$ \\
Juiciness & $7.81 \pm 0.83^{\mathrm{a}}$ & $7.64 \pm 1.23^{\mathrm{a}}$ & $5.67 \pm 1.92^{\mathrm{b}}$ & $5.08 \pm 1.56^{\mathrm{b}}$ \\
Crunchiness & $7.09 \pm 1.31^{\mathrm{a}}$ & $7.83 \pm 1.11^{\mathrm{a}}$ & $5.08 \pm 1.98^{\mathrm{b}}$ & $4.17 \pm 2.12^{\mathrm{b}}$ \\
Toughness & $5.73 \pm 1.66$ & $4.52 \pm 2.06$ & $4.33 \pm 2.57$ & $5.33 \pm 2.74$ \\
Mealiness & $2.83 \pm 1.33^{\mathrm{b}}$ & $2.42 \pm 1.31^{\mathrm{b}}$ & $4.83 \pm 2.08^{\mathrm{a}}$ & $4.67 \pm 2.53^{\mathrm{a}}$ \\
\hline
\end{tabular}

${ }^{1)}$ Means $\pm \mathrm{SD}$ ( $\mathrm{n}=96$ ) within each column followed by the same letter are not significantly different $(\mathrm{p}<0.05)$. 
높은 점수로 평가하였다. 이취와 질김성은 시료 그룹 간에 유의적인 차이가 없다고 평가하였고, 과일의 푸석함을 나 타내는 가루끼는 $\mathrm{A}$ 와 $\mathrm{B}$ 그룹보다는 $\mathrm{C}$ 와 $\mathrm{D}$ 시료 그룹이 높은 점수로 평가하였다.

한편 동일한 시료군의 후지 사과를 소비자 100 명에게 제시하여 소비자 검사를 실시한 결과(Table 3) 사과 표면의 붉은색의 균일성은 $\mathrm{A}$ 그룹이 가장 높은 7.36 \pm 1.24 로 평가하 였고, $\mathrm{B}$ 그룹은 $6.28 \pm 1.58, \mathrm{C}$ 와 $\mathrm{D}$ 는 각각 $2.95 \pm 1.25$ 와 $3.09 \pm 1.79$ 로 평가하여 묘사 분석 결과와 비슷한 값으로 평 가하였다. 사과 껍질의 윤기 특성도 묘사 분석 결과와 유사 한 값으로 평가하였고, 과육의 노란색 강도의 경우도 묘사 분석결과와 비슷하게 평가하였다. 또 사과 향, 단맛, 다즙성, 아삭함, 가루끼 특성 항목도 묘사 분석 결과와 유사한 값으 로 평가하였으나 묘사 분석에서의 이취 $(2.08 \pm 1.16$ $3.67 \pm 2.64)$ 와 질김성 $(4.33 \pm 2.57 \sim 5.73 \pm 1.66)$ 특성항목이 경 우 유의적인 차이가 없다고 평가하였으나, 소비자 기호도 검사의 경우 이취 항목은 2.13 $\pm 1.23 \sim 3.27 \pm 2.01$ 범위의 점수 로 통계분석 결과 유의적인 차이가 있었다.

또 질김성의 경우도 묘사 분석에서는 시료간 유의적인 차이 가 없는 4.33 $\pm 2.57 \sim 5.73 \pm 1.66$ 점수 분포였으나, 소비자 조 사에서는 4.19 $\pm 1.75 \sim 5.08 \pm 1.91$ 점수 분포를 보이면서 통계 적으로는 유의차가 있다고 분석되었다. 일부 특성 항목의
경우 묘사 분석에서는 유의적인 차이가 없다고 한 항목이 소비자 조사에서는 유의적인 차이가 있다고 분석된 결과는 평가하는 시료 수의 개수와 후지 사과 시료의 개체 차이에 의한 분석값으로 여겨진다. 전체적인 기호도는 $\mathrm{A}$ 그룹과 $\mathrm{B}$ 그룹이 각각 $7.02 \pm 1.57$ 과 $6.92 \pm 1.60$ 로 평가하였고, $\mathrm{C}$ 그 룹과 D 그룹은 각각 $3.89 \pm 1.94$ 와 $2.49 \pm 1.28$ 로 평가하여 전 반적으로 사과 껍질의 붉은색 균일성이 높고, 표면의 윤기 가 많으며, 과육의 노란색 강도, 사과향미, 단맛, 다즙성, 아삭함이 높은 시료의 전체적인 기호도가 높다고 평가하 였다.

\section{품질특성간의 상관관계 및 통계분석}

시장 가격별로 구입한 50 개 들이 후지사과의 물리화학적 품질 특성과 관능적 품질 특성의 상관관계를 분석하였다 (Table 4). 후지 사과의 부피와 무게는 $0.1 \%$ 수준에서 양의 상관관계가 있었고, $\mathrm{pH}$ 는 적정산도( $\mathrm{r}=-0.84)$, 가용성고형물 $(\mathrm{r}=-0.72)$, 유리당 $(\mathrm{r}=-0.44)$ 및 유기산 $(\mathrm{r}=-0.53)$ 과 음의 상관 관계가 있는 것으로 나타났다. 적정산도는 가용성고형물 $(\mathrm{r}=0.76)$ 과 유기산 $(\mathrm{r}=0.52)$ 과 양의 상관관계가 있었고, 가용 성고형물 함량은 유리당과 유기산과 양의 상관관계를 보였 다. 적정산도에 비해 HPLC로 산출한 유기산 총량이 많고 적정산도와 유기산 총량 사이에 상관계수가 0.95으로 높은

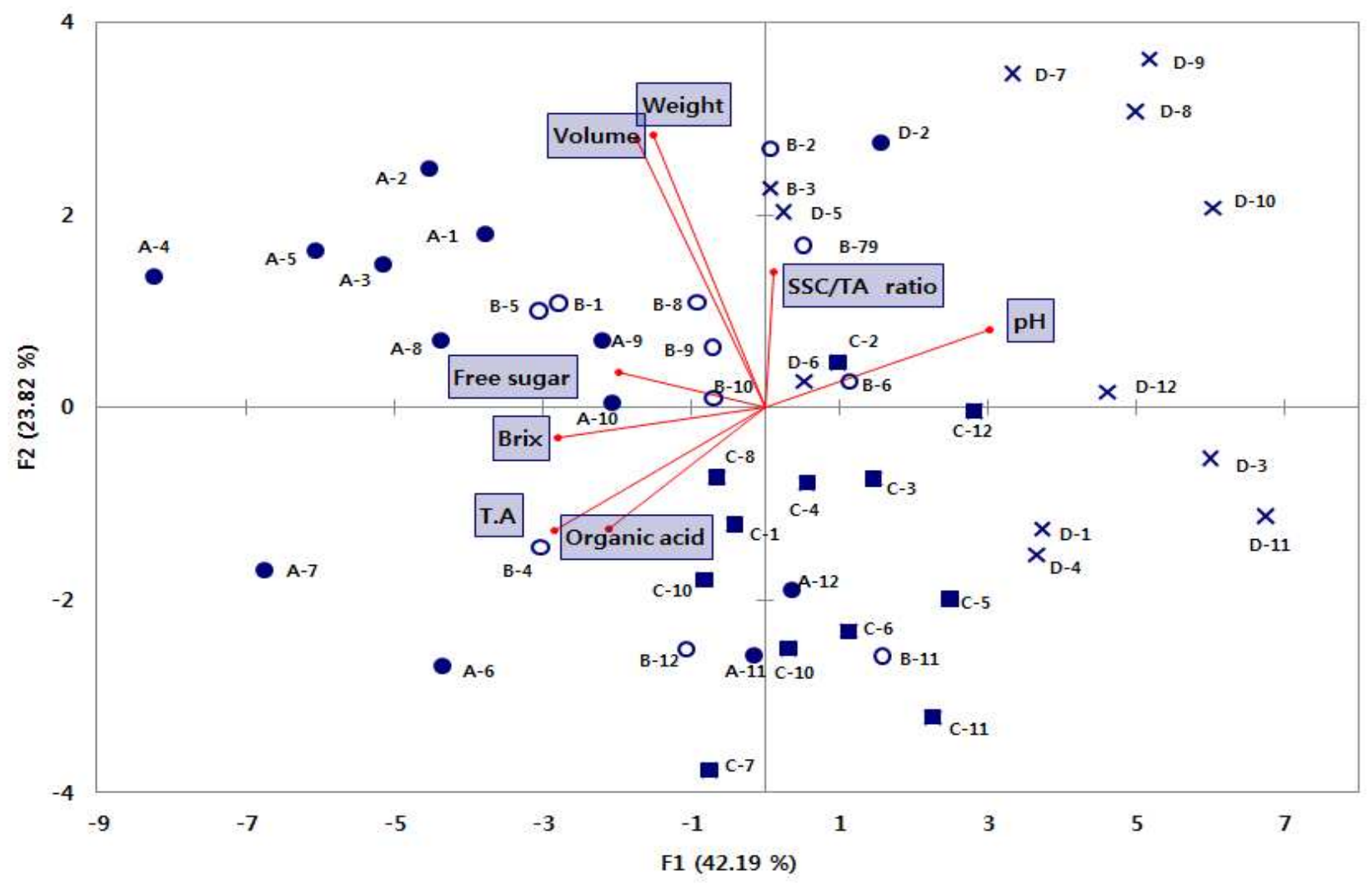

Fig. 1. Principal component analysis of quality characteristics of Fuji apples according to commodity price.

- A group; O, B group; $\mathbf{\square}, \mathrm{C}$ group; $\times$, D group. 

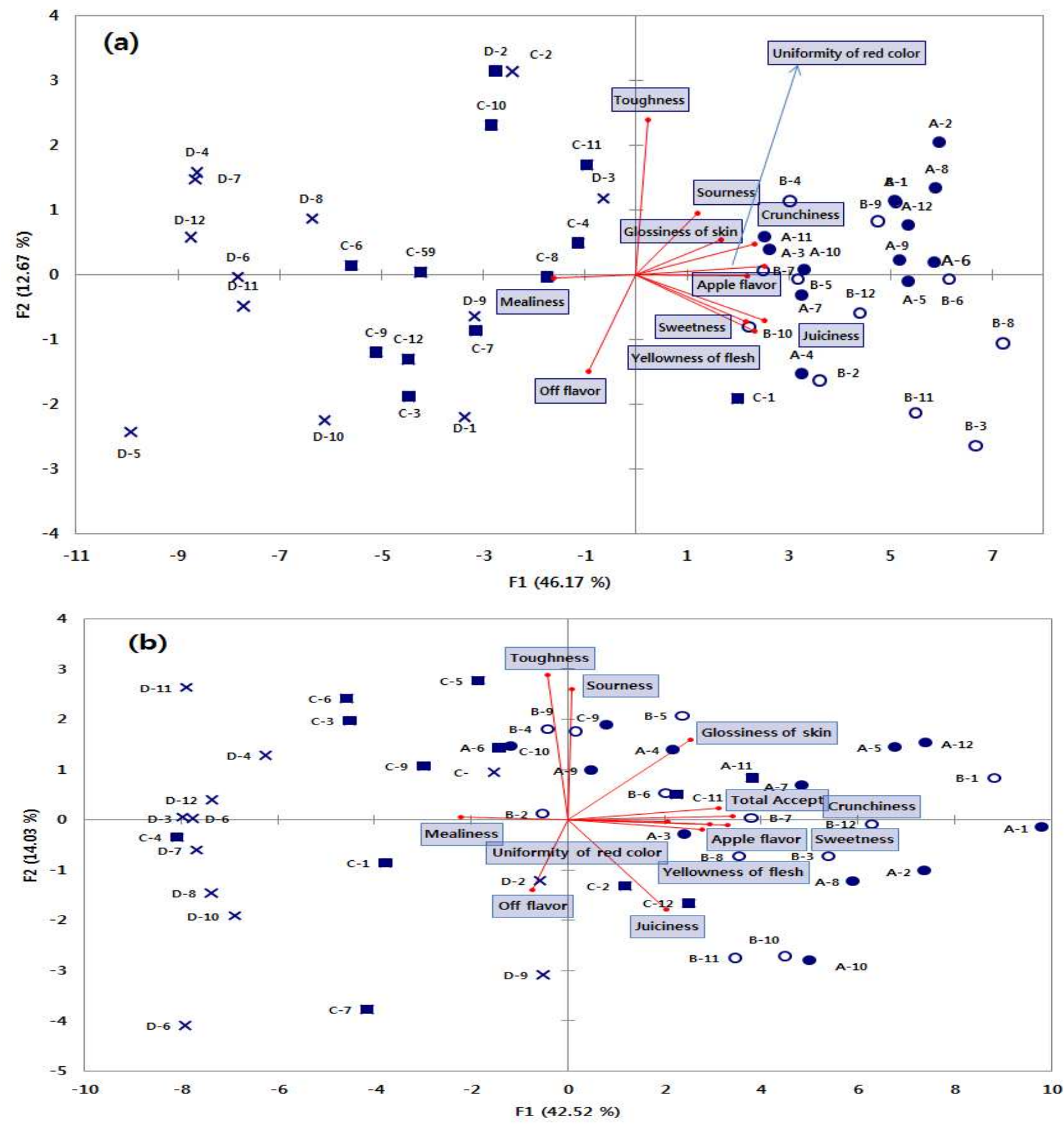

Fig. 2. Principal component analysis of sensory characteristics of Fuji apples according to commodity price.

a, quantitative descriptive analysis; $b$, consumer test.

, A group; $\mathrm{O}, \mathrm{B}$ group; $\mathrm{D}, \mathrm{C}$ group; $\times$, D group

상관성을 보였던 Do 등(23)의 결과와 비교하여 낮은 상관성 을 보였는데, 이는 Shaw 등(24)의 유기산 분석은 조건과 분석 원리에 따라 차이에 의한 것으로 판단된다.

한편 사과 무게와 사과 색의 균일성 $(\mathrm{r}=0.38)$ 과 전반적인 기호도(r=0.33)에서 양의 상관성을 보였고, 푸석푸석함을
나타내는 가루끼 $(\mathrm{r}=-0.36)$ 와 음의 상관성을 보였다. 전체적 인 기호도는 물리화학적 특성인 적정산도 $(\mathrm{r}=0.58)$, 가용성 고형물 $(\mathrm{r}=0.89)$, 당산비 $(\mathrm{r}=0.42)$, 유리당 $(\mathrm{r}=0.36)$ 및 유기산 $(\mathrm{r}=0.38)$ 과 양의 상관성을 나타내었다. 관능특성 항목중 사 과 색의 균일성 $(\mathrm{r}=0.75)$, 과육의 노란색 $(\mathrm{r}=0.73)$, 사과향 
$(\mathrm{r}=0.85)$, 단맛 $(\mathrm{r}=0.91)$, 다즙성 $(\mathrm{r}=0.64)$, 아삭함 $(\mathrm{r}=0.65)$ 과 양 의 상관성을 보였고, 가루끼 $(\mathrm{r}=-0.49)$ 와는 음의 상관성을 나타내었다. 이는 Jung 등(13)의 소비자 기호도와 상관성이 높은 특성은 과육의 노란색과 $\mathrm{pH}$ 와 높은 상관성이 있고, 감각 특성으로는 사과맛, 아삭함, 질김성, 다즙성, 단맛과 양의 상관성을 보였다는 결과와 유사하였다. 또 Manalo(25) 의 사과 특유의 맛과 조직감인 다즙성, 경도 등의 복합적인 특성에 의해 사과의 기호도가 결정된다는 결과와 유사하였 다.

시장 가격별 후지 사과의 물리화학적 품질 특성의 주성 분 분석(principal component analysis) 결과는 Fig. 1과 같다. 첫 번째 주성분(F1)과 두 번째 주성분(F2)는 전체 데이터의 $42.19 \%$ 와 $23.82 \%$ 의 설명력을 보여 주었고, 총설명력은 $66.01 \%$ 였다. 주성분 $\mathrm{F} 1$ 은 $\mathrm{pH}$, 적정산도, 가용성 고형분, 유리당 및 유기산이었고, 주성분 F2는 사과의 무게와 크기 로 물성 특성이었다. 각 품질 특성의 분포를 보면 F1의 오른쪽으로 당산비율과 $\mathrm{pH}$ 가 분포하였고, 왼쪽으로는 사 과 무게, 중량, 유리당, brix, 총산도 및 유기산이 분포되었 다. F2 상으로는 Y축 양의 방향으로 무게, 중량, 당산비, $\mathrm{pH}$, 유리당이 분포하였고, $\mathrm{Y}$ 축 음의 방향으로는 oBrix, 총 산도, 유기산이 분포하였다. 가격별 후지 사과의 분포도를 보면 $\mathrm{A}$ 그룹과 $\mathrm{B}$ 그룹이 $\mathrm{F} 1$ 좌표 상의 왼편에 $\mathrm{C}$ 그룹과 $\mathrm{D}$ 그룹은 오른편에 위치하여 시장 가격별 후지 사과의 물리 화학적 품질 특성에 차이가 있는 것으로 확인하였다. 한편 Fig. 2는 시장 가격별 후지 사과의 전문패널에 의한 묘사 분석 결과(Table 2)와 소비자 기호도 검사(Table 3)에 의한 관능적 품질 특성의 주성분 분석을 실시한 결과이다. 전문 패널에 의한 주성분 분석 결과(a)는 첫 번째 주성분(F1)과

Table 3. Consumer test of Fuji apples according to commodity price

\begin{tabular}{lcccc}
\hline \multirow{2}{*}{ Sensory attributes } & \multicolumn{4}{c}{ Apple samples } \\
\cline { 2 - 5 } & $\mathrm{A}$ & $\mathrm{B}$ & $\mathrm{C}$ & $\mathrm{D}$ \\
\hline Uniformity of red color & $7.36 \pm 1.24^{\mathrm{all}}$ & $6.28 \pm 1.58^{\mathrm{b}}$ & $2.95 \pm 1.25^{\mathrm{c}}$ & $3.09 \pm 1.79^{\mathrm{c}}$ \\
Glossiness of skin & $6.75 \pm 1.38^{\mathrm{a}}$ & $5.27 \pm 1.91^{\mathrm{b}}$ & $3.77 \pm 1.81^{\mathrm{c}}$ & $3.40 \pm 2.04^{\mathrm{c}}$ \\
Yellowness of flesh & $6.79 \pm 1.76^{\mathrm{a}}$ & $6.95 \pm 1.45^{\mathrm{a}}$ & $5.14 \pm 1.74^{\mathrm{b}}$ & $3.81 \pm 1.78^{\mathrm{c}}$ \\
Apple flavor & $7.18 \pm 1.21^{\mathrm{a}}$ & $7.00 \pm 1.44^{\mathrm{a}}$ & $4.55 \pm 1.93^{\mathrm{b}}$ & $2.86 \pm 1.51^{\mathrm{c}}$ \\
Off flavor & $2.13 \pm 1.23^{\mathrm{b}}$ & $2.38 \pm 1.47^{\mathrm{b}}$ & $2.99 \pm 1.62^{\mathrm{a}}$ & $3.27 \pm 2.01^{\mathrm{a}}$ \\
Sweetness & $6.64 \pm 1.46^{\mathrm{a}}$ & $6.81 \pm 1.56^{\mathrm{a}}$ & $4.07 \pm 1.84^{\mathrm{b}}$ & $2.56 \pm 1.39^{\mathrm{c}}$ \\
Sourness & $5.27 \pm 2.04^{\mathrm{a}}$ & $4.30 \pm 2.08^{\mathrm{b}}$ & $4.95 \pm 2.21^{\mathrm{a}}$ & $3.92 \pm 2.24^{\mathrm{b}}$ \\
Juiciness & $7.03 \pm 1.46^{\mathrm{a}}$ & $6.94 \pm 1.36^{\mathrm{a}}$ & $5.43 \pm 1.62^{\mathrm{b}}$ & $5.19 \pm 2.01^{\mathrm{b}}$ \\
Crunchiness & $7.19 \pm 1.47^{\mathrm{a}}$ & $6.75 \pm 1.56^{\mathrm{a}}$ & $4.71 \pm 2.15^{\mathrm{b}}$ & $4.28 \pm 1.93^{\mathrm{b}}$ \\
Toughness & $4.98 \pm 1.78^{\mathrm{a}}$ & $4.19 \pm 1.75^{\mathrm{b}}$ & $4.61 \pm 1.94^{\mathrm{ab}}$ & $5.08 \pm 1.91^{\mathrm{a}}$ \\
Mealiness & $3.38 \pm 1.88^{\mathrm{b}}$ & $3.17 \pm 1.60^{\mathrm{b}}$ & $4.34 \pm 2.04^{\mathrm{a}}$ & $4.61 \pm 1.98^{\mathrm{a}}$ \\
Total acceptability & $7.02 \pm 1.57^{\mathrm{a}}$ & $6.92 \pm 1.60^{\mathrm{a}}$ & $3.89 \pm 1.94^{\mathrm{b}}$ & $2.49 \pm 1.28^{\mathrm{c}}$ \\
\hline
\end{tabular}

\footnotetext{
${ }^{1)}$ Means $\pm \mathrm{SD}(\mathrm{n}=100)$ within each column followed by the same letter are not significantly
} different $(\mathrm{p}<0.05)$.
두 번째 주성분(F2)는 전체 데이터의 $42.52 \%$ 와 $14.03 \%$ 이 설명력을 보였고, 총설명력은 $56.55 \%$ 였다. 또 소비자 검사 결과에 의한 주성분 분석 결과(b)는 첫 번째 주성분(F1)과 두 번째 주성분(F2)는 전체 데이터의 $46.17 \%$ 와 $12.67 \%$ 이 설명력을 보였고, 총설명력은 $55.84 \%$ 로 전문패널원에 의 한 주성분 분석 결과와 유사한 설명력을 보였다. 전문패널 에 의한 결과와 소비자 기호도 검사 결과와 상관없이 주성 분 F1은 붉은색의 균일성, 표면의 윤기, 과육의 노란색, 사과향미, 단맛, 다즙성, 가루끼(푸석함)있었고, 주성분 F2 는 신맛과 질김성, $\mathrm{F} 3$ 는 아삭함과 이취였다. 각 관능적 품질 특성의 분포를 보면 전문패널에 의한 결과와 소비자 검사 결과와 유사한 패턴을 보여 $\mathrm{F} 1$ 의 왼쪽 부분에는 가루끼(푸 석함)와 이취가 분포되었고 그 외의 특성 항목은 오른쪽에 분포하였다. 가격별 후지 사과의 관능특성 항목의 분포도 의 경우 $\mathrm{A}$ 그룹과 $\mathrm{B}$ 그룹이 $\mathrm{F} 1$ 좌표 상의 오른쪽에 $\mathrm{C}$ 그룹과 $\mathrm{D}$ 그룹은 왼쪽에 위치하여 시장 가격별 후지 사과의 물리화 학적 품질 특성에 차이가 있는 것으로 확인하였다.

이상의 결과에서 현재 시장에서 유통되고 있는 동일 등 급의 후지 사과의 경우 최후지 사과의 무게와 부피는 시료 간 유의한 차이가 없었으며, $\mathrm{pH}$ 와 적정산도는 $\mathrm{A}$ 그룹이 가장 낮은 $3.99,0.32 \%$ 였고, 가용성고형물 함량의 경우도 $\mathrm{A}$ 그룹과 B 그룹은 $13.73 ~ 13.9 \%$ 였고, C 그룹과 D 그룹은 각각 $11.19 \%, 9.16 \%$ 로 그룹 간 차이가 있었다. 또 총 유리당 은 $\mathrm{A}(11.96 \%)>\mathrm{B}(10.53 \%>\mathrm{C}(9.61 \%)>\mathrm{D}(7.47 \%)$ 의 순이었고, 유기산 함량은 $\mathrm{A}(386.29 \mathrm{mg} \%)>\mathrm{B}, \mathrm{C}, \mathrm{D}(344.23 \mathrm{mg} \%, 359.23$ $\mathrm{mg} \%, 320.09 \mathrm{mg} \%$ )로 그룹 간에 차이를 보였다. 관능특성의 경우 묘사 분석과 소비자 검사 결과, 통계적으로 붉은색의 균일성, 과육의 노란색 강도, 사과 향미, 단맛, 신맛, 다즙성, 아삭거림 등의 특성 항목에서 $\mathrm{A}$ 와 $\mathrm{B}$ 그룹과 $\mathrm{C}$ 와 $\mathrm{D}$ 그룹은 확실하게 구분을 하였다. 또 소비자 검사에 의한 전체적인 기호도는 A 그룹과 B 그룹이 각각 $7.02 \pm 1.57$ 과 $6.92 \pm 1.60$ 로 평가하였고, C 그룹과 D 그룹은 각각 $3.89 \pm 1.94$ 와 $2.49 \pm$ 1.28 로 평가하였다. 즉 시장가격에 따라 유리당, 유기산, 고형분 함량 등의 함량에는 차이가 있었으나 실제 맛을 보았을 때 가장 가격이 높았던 $\mathrm{A}$ 그룹(115,000원 $/ 15 \mathrm{~kg}$ )과 $\mathrm{B}$ 그룹 $(84,000$ 원 $/ 15 \mathrm{~kg})$ 은 유의적 차이가 없었고, C 그룹 (59,000원 $/ 15 \mathrm{~kg}), \mathrm{D}$ 그룹 $(37,500$ 원 $/ \mathrm{kg})$ 은 차이를 있다고 평 가하였다. 즉 시장에서 판매되고 있는 동일한 크기의 사과 의 경우 가격에 의해 이화학적 품질과 관능적 특성 항목에 차이를 보였다. 본 연구는 2014년 11월에 수확한 후지 사과 만을 대상이고 50 개 들이 4그룹만을 대상으로 한 결과이므 로 농산물의 특성상 작황과 개체에 따라 품질 특성 차이가 커서 이에 대한 데이터 축적이 요구된다.

\section{요 약}

본 연구는 소비자가 원하는 후지사과의 품질 등급을 위 
Table 4. Correlation coefficient between sensory attributes by consumer and quality characteristics of $F u j i$ apples according to commodity price

\begin{tabular}{|c|c|c|c|c|c|c|c|c|c|c|c|c|c|c|c|c|c|c|c|c|c|}
\hline & \multicolumn{8}{|c|}{ Physicochemical properties } & \multicolumn{12}{|c|}{ Sensory evaluation } \\
\hline & & \multirow[t]{2}{*}{ Volume } & \multirow[t]{2}{*}{ Weight } & \multirow[t]{2}{*}{$\mathrm{pH}$} & \multirow[t]{2}{*}{ T.A } & \multirow[t]{2}{*}{ SSC } & \multirow[t]{2}{*}{ SSCTA } & \multirow{2}{*}{$\begin{array}{l}\text { Total free } \\
\text { sugar }\end{array}$} & \multirow{2}{*}{$\begin{array}{c}\text { Total } \\
\text { organic acid }\end{array}$} & Uniform & Glossiness & Yellowness & $\begin{array}{l}\text { Apple } \\
\text { flavor }\end{array}$ & $\begin{array}{c}\text { Off } \\
\text { flavor }\end{array}$ & Sweetness & Sourness & Juiciness & $\begin{array}{c}\text { Crunchi- } \\
\text { ness }\end{array}$ & $\begin{array}{c}\text { Tough- } \\
\text { ness }\end{array}$ & Mealiness & $\begin{array}{r}\text { Total } \\
\text { Accept. }\end{array}$ \\
\hline & & & & & & & & & & \multicolumn{2}{|c|}{ Skin } & \multicolumn{10}{|c|}{ Flesh } \\
\hline & Volume & 1.00 & $0.98^{\mathrm{x} \times \mathrm{x}+1)}$ & -0.20 & 0.12 & 0.18 & 0.09 & 0.23 & 0.00 & $0.31^{*}$ & 0.09 & -0.11 & 0.18 & 0.06 & 0.16 & 0.08 & -0.03 & 0.09 & -0.06 & -0.28 & 0.24 \\
\hline & Weight & & 1.00 & -0.27 & 0.16 & 0.26 & 0.14 & 0.29 & 0.04 & $0.38^{*}$ & 0.12 & -0.06 & 0.25 & 0.00 & 0.24 & 0.13 & 0.04 & 0.15 & -0.04 & $-0.36^{*}$ & $0.33^{*}$ \\
\hline & $\mathrm{pH}$ & & & 1.00 & $-0.84^{* *}$ & $-0.72^{* * x}$ & 0.19 & $-0.44^{* *}$ & $-0.53^{* *}$ & $-0.51^{* *}$ & $-0.53^{* *}$ & $-0.36^{*}$ & $-0.42^{* *}$ & 0.26 & $-0.48^{* * t}$ & $-0.31^{*}$ & $-0.42^{* *}$ & $-0.32^{*}$ & 0.01 & 0.18 & $-0.59^{* *}$ \\
\hline \multicolumn{2}{|c|}{ Titratable acidity } & & & & 1.00 & $0.76^{* *}$ & $-0.34^{*}$ & 0.27 & $0.52^{* *}$ & $0.47^{\text {*t }}$ & $0.54^{* t}$ & $0.40^{*}$ & $0.46^{* *}$ & $-0.30^{*}$ & $0.47^{* *}$ & $0.38^{*}$ & $0.34^{*}$ & $0.30^{*}$ & -0.07 & -0.13 & $0.58^{* *}$ \\
\hline \multicolumn{2}{|c|}{ Soluble solid content } & & & & & 1.00 & $0.32^{*}$ & $0.37^{*}$ & $0.44^{* *}$ & $0.75^{* * * x}$ & $0.63^{k+k * x}$ & $0.65^{* * *}$ & $0.79^{* * *}$ & $-0.36^{*}$ & $0.77^{\text {tit }}$ & $0.39^{*}$ & $0.63^{* *}$ & $0.64^{* *}$ & 0.08 & $-0.41^{*}$ & $0.89^{* * * x}$ \\
\hline \multicolumn{2}{|c|}{ SSCTA } & & & & & & 1.00 & 0.09 & -0.08 & $0.40^{* * i}$ & 0.08 & $0.36^{*}$ & $0.44^{* *}$ & -0.06 & $0.43^{* *}$ & 0.00 & $0.38^{*}$ & $0.44^{* * x}$ & 0.17 & $-0.34^{*}$ & $0.42^{*}$ \\
\hline \multicolumn{2}{|c|}{ Total free sugar } & & & & & & & 1.00 & $0.32^{*}$ & $0.42^{* *}$ & $0.52^{* * 2}$ & 0.20 & $0.36^{*}$ & -0.19 & $0.30^{*}$ & 0.15 & 0.20 & $0.31^{*}$ & 0.12 & -0.22 & $0.36^{*}$ \\
\hline \multicolumn{2}{|c|}{ Total organic acid } & & & & & & & & 1.00 & $0.28^{*}$ & $0.29^{*}$ & 0.27 & 0.22 & -0.08 & $0.30^{*}$ & 0.09 & 0.28 & 0.15 & -0.14 & 0.02 & $0.38^{*}$ \\
\hline \multirow{2}{*}{ 'Skin } & Uniformity & & & & & & & & & 1.00 & $0.56^{\text {tix }}$ & $0.49^{* *}$ & $0.62^{* * *}$ & -0.14 & $0.68^{\text {titx }}$ & 0.28 & $0.62^{* *}$ & $0.43^{* *}$ & 0.12 & $-0.41^{*}$ & $0.75^{* *+x}$ \\
\hline & Glossiness & & & & & & & & & & 1.00 & $0.37^{*}$ & $0.40^{* *}$ & -0.25 & $0.45^{* t}$ & 0.16 & 0.32 & $0.37^{*}$ & 0.13 & $-0.36^{*}$ & $0.49^{* *}$ \\
\hline \multirow{10}{*}{ Flesh } & Yellowness & & & & & & & & & & & 1.00 & $0.71^{k * *}$ & -0.22 & $0.79^{\text {tith }}$ & 0.24 & $0.67^{* * t}$ & $0.68^{\text {tkik }}$ & -0.20 & $-0.34^{*}$ & $0.73^{* * * *}$ \\
\hline & Apple flavor & & & & & & & & & & & & 1.00 & $-0.37^{*}$ & $0.79^{4 * x}$ & $0.54^{4 * x}$ & $0.56^{\text {t* }}$ & $0.76^{\text {tikx }}$ & 0.00 & $-0.42^{*}$ & $0.85^{*+* x}$ \\
\hline & Off flavor & & & & & & & & & & & & & 1.00 & -0.22 & -0.06 & 0.02 & -0.35 & -0.22 & 0.11 & -0.27 \\
\hline & Sweetness & & & & & & & & & & & & & & 1.00 & $0.30^{*}$ & $0.68^{\text {t*t }}$ & $0.64^{t+k x}$ & -0.15 & $-0.46^{\text {t*t }}$ & $0.91^{*+* x}$ \\
\hline & Sourness & & & & & & & & & & & & & & & 1.00 & 0.15 & $0.34^{*}$ & 0.21 & -0.10 & $0.34^{*}$ \\
\hline & Juiciness & & & & & & & & & & & & & & & & 1.00 & $0.60^{* * * x}$ & 0.06 & $-0.42^{*}$ & $0.64^{* * * x}$ \\
\hline & Crunchiness & & & & & & & & & & & & & & & & & 1.00 & 0.21 & $-0.42^{*}$ & $0.65^{* 3 * x}$ \\
\hline & Toughness & & & & & & & & & & & & & & & & & & 1.00 & -0.11 & -0.07 \\
\hline & Mealiness & & & & & & & & & & & & & & & & & & & 1.00 & $-0.49^{* *}$ \\
\hline & Total Accept & & & & & & & & & & & & & & & & & & & & 1.00 \\
\hline
\end{tabular}

1) significant at $\mathrm{p}<0.05,{ }^{* *}$ significant at $<0.01,{ }^{* * *}$ significant at $\mathrm{p}<0.001$.

한 기초 데이터를 제공하기 위하여 시장에서 판매되고 있는 상품 가격에 따른 후지 사과의 품질 특성 및 관능특성을 조사하였다. 시장 가격별(4그룹, 50 개들이)로 후지 사과의 무게와 부피는 시료 간 유의적인 차이가 없었으며, $\mathrm{pH}$ 와 적정산도는 $\mathrm{A}$ 그룹이 가장 낮은 $3.99,0.32 \%$ 였고, 가용성 고형분 함량과 총 유리당 함량의 경우 가격이 비교적 높은 $\mathrm{A}$ 그룹과 B 그룹이 저가의 C 그룹과 D 그룹보다 높았다. 또 유기산은 A 그룹의 시료가 가장 높은 함량인 386.29 $\mathrm{mg} \%, \mathrm{~B}, \mathrm{C}, \mathrm{D}$ 그룹은 $320.09 \sim 359.23 \mathrm{mg} \%$ 였다. 한편 훈련된 전문패널에 의한 묘사 분석 결과 사과 외관의 붉은색의 균일성과 사과 껍질의 윤기의 경우 $\mathrm{A}$ 그룹 가장 높게 평가 하였다. 과육의 노란색 정도, 사과향, 단맛, 다즙성, 아삭함 의 관능특성에서 $\mathrm{A}$ 그룹과 $\mathrm{B}$ 그룹이 $\mathrm{C}$ 와 $\mathrm{D}$ 그룹보다 높은 점수로 평가하였다. 또 동일한 시료군의 후지 사과를 소비 자 검사를 실시한 결과 전반적으로 묘사 분석 결과의 비슷 하게 평가하였고, 전체적인 기호도는 A 그룹과 B 그룹이 각각 7.02 과 6.92 로 평가하였고, C 그룹과 D 그룹은 각각 3.89 와 2.49로 평가하였다. 후지사과의 품질 특성과 관능적 품질 특성 상관관계 분석 결과 중 전체적인 기호도는 적정 산도 $(\mathrm{r}=0.58)$, 가용성 고형분 $(\mathrm{r}=0.89)$, 당산비 $(\mathrm{r}=0.42)$, 유리 당 $(\mathrm{r}=0.36)$ 및 유기산 $(\mathrm{r}=0.38)$ 과 양의 상관성을 나타내었다. 물리화학적 품질 특성의 주성분 분석 결과 총설명력은 $66.01 \%$ 이었고, 주성분 $\mathrm{F} 1$ 은 $\mathrm{pH}$, 적정산도, 가용성 고형분,
유리당 및 유기산이었고, 주성분 F2는 사과의 무게와 크기 로 물성 특성이었다. 또 관능적 품질 특성의 주성분 분석을 실시한 결과, 전문패널에 의한 주성분 분석 결과(a)는 총설 명력은 $56.55 \%$ 였고, 소비자 검사 결과에 의한 주성분 분석 결과(b)는 총설명력은 $55.84 \%$ 로 전문패널원에 의한 주성분 분석 결과와 유사한 설명력을 보였다.

\section{감사의 글}

본 연구는 한국식품연구원 출연금 과제 연구 지원으로 수행되었으며, 이에 감사드립니다.

\section{References}

1. Apple Research Institute (2005) Monthly apple love story, 1 (www.iloveapple.co.kr) (accessed, May 2016)

2. Ministry of Agriculture, Food and Rural Affairs (MAFRA) (2015) Statistics of agricultural product amount, MAFRA (http://lib.mafra.go.kr) (accessed, May 2016)

3. Choi YH, Lee SJ (2005) A survey on uses, preference and recognition of apple. Korean J Food Cult, 20, 204-213 
4. Park HW, Yoon JY, Kim YH, Lee SA, Cha HS (2007) Customer preferences for 'Fuji' apples stored using functional modified atmosphere film. Korean J Food Preserv, 14, 105-108

5. Kim KP, Park MS (2007) Consumer preferences for fruit size and their implication. Korean J Food Marketing Economic, 24, 26-39

6. KREI (2007) Agricultural outlook 2007. Korean Rural Economic Institute, Seoul, Korea, p 710

7. Kajikawa C (1998) Quality level and price in Japanese apple market. Agribusiness, 14, 227-234

8. Kim Kp, Kim YH, Park JH (2004) An analysis on the change of consumer's fruit purchasing behavior. J Rural Development, 27, 55-66

9. Cho SD, Kim DM, Kim GH (2008) Survey on consumer perceptions of the sensory quality attributes of apple. Korean J Food Preserv, 15, 810-815

10. Bonany J, Buehler A, Carbo J, Codarin S, Donati F, Echeverria G, Egger S, Guerra W, Hilaire C, Holler I, Iglesias I, Jesionkowska K, Konopacka D, Kruczynask D, Matinelli A, Pitiot C, Sansavini S, Stehr R, Schoorl F (2013) Consumer eating quality acceptance of new apple varieties in different European countries. Food Qual Pref, 30, 250-259

11. Seppa L, Railio J, Vehkalahti K, Tahvonen R, Tuorila H (2013) Hedonic responses and individual definitions of an ideal apple as predictors of choice. J Sens Stud, 28, 346-357

12. Food Code (2015) Ministry of Food and Drug Safety

13. Jung HY, Kim SS (2014) Identification of ideal size and drivers for consumer acceptability of apple. Korean J Food Preserv, 21, 618-626

14. Corollaro ML, Endrizzi I, Bertolini A, Aprea E, Dematte ML, Costa F, Biasioli F, Gasperi F (2013) Sensory profiling of apple: methodological aspects, cultivar characterization and postharvest changes. Postharvest Biol Technol, 77, 111-120
15. Addinosoft (2010) Xlstat, Data analysis and statistics with MS excel. Addinsoft, Paris, France

16. NAQS (2015) Agricultural standards notice no. 2013-42. National Agricultural Products Quality Management Service, Gimchoen, Korea, p 16, 34

17. Elkins ER, Heuser JR, Chin H (1988) Detection of adulteration in selected fruit juices. In: Adulteration of fruit juice beverages, Nagy S, Attaway JA, Rhodes ME (Editors), Marcel Decker, NY, USA, p 317-314

18. Fuleki T, Pelayo E, Palabay RB (1994) Sugar composition of varietal juices produced from fresh and stored apples. J Agric Food Chem, 42, 1266-1275

19. Lee HS, Wrolade RE (1988) Detection of adulteration in apple juices. In: Adulteration of fruit juice beverages, Nagy S, Attaway JA, Rhodes ME (Editors), Marcel Dekker, New York, USA, p 343-376

20. Kim CH, Whang HJ, Ku JE, Park KW, Yoon KR (2006) Free sugars content of selected Korean apple cultivars. Korean J Food Sci Technol, 38, 22-27

21. Brause AR, Raterman JM (1982) Verification of authenticity of apple juice. J Assoc Off Anal Chem, 65, 846-849

22. Wrolstad RE, Shallenberger RS (1981) Free sugars and sorbitol in fruits-A complication from the literature. J Assoc Off Anal Chem, 64, 91-103

23. Do YS, Whang HJ, Ku JE, Yoon KR (2005) Organic acids content of the selected Korean apple cultivars. Korean J Food Sci Technol, 37, 922-927

24. Shaw PE, Wilson CW (1983) Organic acids in orange, grape fruit and cherry juices quantified by highperformance liquid chromatography using neutral resin or propylamine columns. J Sci Food Agric, 34, 1285-1288

25. Manalo AB (1990) Assessing the importance of apple attributes: An agricultural application of conjoint analysis. Northeastern J Agric Res Econ, 19, 118-124 